\title{
Pengaruh Penggunaan Koin Bermuatan terhadap Kepercayaan Diri Siswa pada Operasi Bilangan Bulat
}

\author{
Siti Makmudah ${ }^{*}$, Yusuf Adhitya ${ }^{2}$ \\ 1SMP Negeri 2 Adimulyo, Kebumen, Indonesia; \\ *mudahmukti@gmail.com \\ 2 Magister Pendidikan Matematika, SPs Universitas Pendidikan Indonesia, Bandung, \\ Indonesia; \\ yusufadhitya@upi.edu
}

\begin{abstract}
Abstrak. Penelitian ini bertujuan untuk mengetahui pengaruh penggunaan "koin bermuatan" terhadap kepercayaan diri siswa kelas VII SMP Negeri 2 Adimulyo pada operasi bilangan bulat. Penelitian ini menggunakan metode penelitian Quasi Experiment dengan postrespons-only control design. Populasi pada penelitian ini adalah seluruh siswa kelas VII SMP Negeri 2 Adimulyo dengan sampel penelitian berjumlah 64 siswa yang terdiri dari 32 siswa kelas VII G dan 32 siswa kelas VII H. Data tersebut dianalisis menggunakan uji Mann-Whitney. Berdasarkan hasil analisis data diperoleh nilai signifikansi 0,0000195 < 0,05 sehingga hipotesis diterima. Dengan kata lain, terdapat pengaruh yang signifikan penggunaan koin bermuatan terhadap kepercayaan diri siswa pada operasi bilangan bulat.
\end{abstract}

Kata Kunci: koin bermuatan, kepercayaan diri, operasi bilangan bulat.

\begin{abstract}
The study aims to know how the use of "charged coin" influences selfconfidence of student grade 7 SMP Negeri 2 Adimulyo in integer operation. This research used quasi experimental with postrespons-only control design. The population was all students grade 7 SMP Negeri 2 Adimulyo which the sample were 64 students consisting of 32 students from class VII G and 32 students from class VII G. Data was analyzed by Mann-Whitney test. Based on the data analysis, it was obtained that significancy value is $0,0000195<0,05$ so the hypothesis is accepted. In other words, there is a significant influence of the use of "charged coin" against student's self-confidence in integer operation.
\end{abstract}

Keywords: charge coin, self-confidence, integer operation

\section{Pendahuluan}

Pembelajaran di sekolah tidak hanya mempunyai kewajiban membangun kemampuan kognitif siswanya. Pembelajaran di sekolah juga dituntut membentuk sikap dan karakter siswa melalui setiap mata pelajaran, tidak terkecuali matematika. Matematika harus dapat berperan membangun sikap siswa. Salah satunya adalah sikap percaya diri. Pada pembelajaran matematika, sikap percaya diri tentu dibutuhkan dalam mewujudkan 
interaksi antara guru dan siswa. Ketika siswa tidak ada yang percaya diri maka sudah tentu pembelajaran hanya bersifat ceramah.

Menurut Kementerian Pendidikan dan Kebudayaan (2014), kepercayaan diri adalah kondisi mental seseorang yang mampu memberikan dorongan untuk berprestasi melalui tindakan. Pada konteks pembelajaran, sikap siswa yang percaya diri dapat berupa bertanya, presentasi, dan mengemukaan pendapat. Dengan sikap percaya diri, siswa akan termotivasi untuk selalu percaya akan usaha dan kemampuan sendiri sehingga tidak gampang menyerah ketika mengalami kegagalan (Khrisna, 2006). Selain itu, siswa yang memiliki kepercayaan diri tinggi, mereka akan mampu mengelola proses belajarnya dengan baik, tanpa bergantung kepada orang lain (Pratiwi \& Laksmiwati, 2016). Terlebih rasa percaya diri juga terbukti berperan dalam menentukan prestasi akademik siswa (Hannula, Maijala \& Pehkonen, 2004). Namun, faktanya berdasarkan observasi, peran matematika dalam membangun sikap percaya diri masih belum optimal.

Sikap percaya diri dalam pembelajaran matematika harus dibangun dari dua sisi. Pertama, siswa juga harus menyadari bahwa percaya diri itu penting untuk memperoleh nilai matematika yang baik (Achdiyat \& Lestari, 2016). Di sisi lain, pembelajaran matematika perlu dibuat menyenangkan dan mengakomodir peran siswa sehingga proses membangun sikap percaya diri siswa dapat terbangun. Ketika guru hanya berceramah, siswa tidak merasa terakomodir sehingga mereka berbicara sendiri dan tidak berkonsentrasi (Winarsih, 2009). Padahal apabila siswa mampu diajak berperan aktif, siswa akan berlatih percaya diri dan akhirnya menyukai matematika. Hal ini sejalan dengan penelitian Siregar (2017) yang menyebutkan bahwa 85\% siswa SD kelas $\mathrm{V}$ menyukai pembelajaran matematika apabila pembelajarannya menyenangkan seperti menggunakan game. Walaupun penelitian tersebut menggunakan subjek siswa SD, namun secara karakteristik dan perkembangan kognitif masih sama-sama pada tahap operasional konkret. Oleh karena itu, penelitian tersebut dapat dijadikan gambaran bahwa siswa secara umum menyukai pembelajaran matematika yang menyenangkan.

Proses membangun pembelajaran matematika yang menyenangkan dapat dilakukan dengan berbagai cara. Salah satunya adalah penggunaan alat peraga. Alat peraga merupakan salah satu media fisik yang sering digunakan untuk membantu proses pembelajaran matematika. Pada konteks

Copyright (c) 2020

Buana Matematika :

Jurnal Ilmiah Matematika dan Pendidikan Matematika 
operasi bilangan bulat, terdapat berbagai jenis alat peraga yang dapat digunakan seperti mistar, permainan mobil berjalan, dan koin bermuatan (Octavianingsih, 2015). Peneliti tertarik untuk menggunakan alat peraga koin bermuatan karena dirasa lebih realistik dalam merepresentasikan bilangan bulat. Terlebih pada alat peraga koin bermuatan, siswa dapat dikenalkan sejak awal bilangan positif, negatif, dan bilangan netral (bilangan nol). Alat peraga koin bermuatan ini juga dapat digunakan untuk mengajarkan keempat operasi dasar pada billangan bulat (penjumlahan, pengurangan, perkalian, dan pembagian). Berikut gambaran alat peraga koin bermuatan

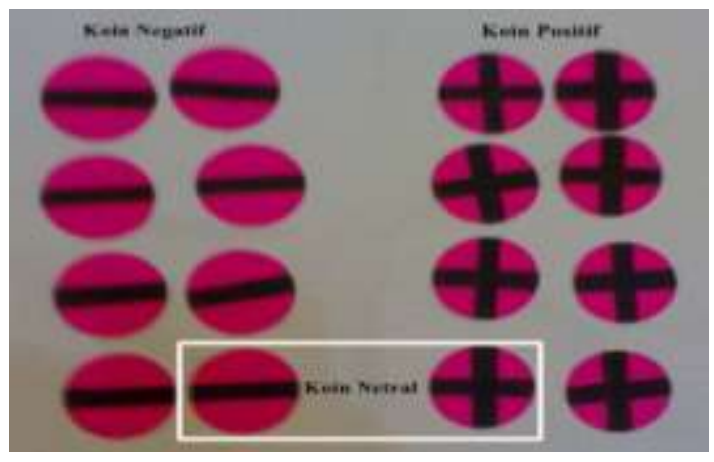

Gambar 1. Alat Peraga Koin Bermuatan

Terdapat beberapa penelitian yang telah dilakukan untuk mengaplikasikan alat peraga koin bermuatan. Contohnya, penelitian Suandini (2013) yang berupa Penelitian Tindakan Kelas (PTK) yang menfokuskan pada pemahaman siswa SD pada materi penjumlahan dan pengurangan bilangan bulat. Pada penelitian tersebut, peneliti sebelumnya belum mengaplikasikan pada topik perkalian dan pembagian. Selain itu, Octavianingsih (2015) juga dalam penelitian dokumenternya menyebutkan bahwa koin bermuatan merupakan salah satu media yang tepat untuk mengajarkan bilangan bulat pada SD. Penelitian dokumenter tersebut merujuk pada makalah terkait pengembangan media pembelajaran dan belum menjelaskan aplikasinya dalam penelitian di lapangan. Peneliti sejauh ini juga hanya menemukan penelitian terkait alat peraga koin bermuatan hanya dilakukan untuk subjek penelitian siswa SD. Padahal materi operasi bilangan bulat juga diajarkan di jenjang SMP pada kelas VII semester 1. Dengan demikian, belum ditemukan penelitian yang membahas apakah penggunaan alat peraga koin bermuatan juga efektif pada jenjang SMP khususnya pada semua operasi bilangan bulat (termasuk perkalian dan pembagian). Selain itu, belum ada penelitian yang secara spesifik membahas bagaimana alat peraga koin bermuatan ini mempengaruhi kemampuan afektif seperti kepercayaan diri siswa. Dari uraian di atas, peneliti merasa perlu untuk membuat penelitian yang fokus

Copyright $@ 2020$

\section{Buana Matematika :}

Jurnal Ilmiah Matematika dan Pendidikan Matematika 
membahas pengaruh penggunaan alat peraga koin bermuatan terhadap kepercayaan diri siswa kelas VII pada materi operasi bilangan bulat.

\section{Metode}

Penelitian ini dilakukan di SMP Negeri 2 Adimulyo, kabupaten Kebumen, Jawa Tengah. Penelitian ini merupakan penelitian kuantitatif dengan menggunakan metode Quasi Experimental Research dengan desain postresponsonly control design. Populasi penelitian ini adalah seluruh siswa kelas VII SMP Negeri 2 Adimulyo. Peneliti menggunakan teknik random sampling dengan sampel sebanyak dua kelas yakni kelas VII G sebagai kelas kontrol dan kelas VII H sebagai kelas eksperimen. Langkah-langkah pada penelitian ini meliputi : 1) mengobservasi, 2) menyusun hipotesis, 3) merancang instrumen berupa angket kepercayaan diri dan alat peraga bermuatan, 4) mengumpulkan data, 4) menganalisis data, dan 5) mengambil kesimpulan.

Pada langkah observasi, peneliti menggunakan data dari pengamatan pembelajaran sehari-hari dan mengkaji beberapa teori. Tahap selanjutnya, peneliti menyusun hipotesis yakni tingkat kepercayaan diri siswa kelas VII pada materi operasi bilangan bulat pada kelas yang menggunakan koin bermuatan secara signifikan lebih tinggi dibandingkan kelas yang menggunakan pembelajaran konvensional. Untuk membuktikan hipotesis tersebut, peneliti merancang instrumen berupa angket kepercayaan diri dan alat peraga koin bermuatan. Angket kepercayaan diri yang digunakan merupakan adaptasi dari penelitian Putri (2019) dengan menggunakan 4 indikator yaitu percaya pada kemampuan diri sendiri (KD1), bertindak mandiri dalam mengambil keputusan (KD2), memiliki konsep diri yang positif (KD3), dan berani mengungkapkan pendapat (KD4). Sementara itu, alat peraga koin yang dibuat juga merupakan modifikasi dari penelitian Suandini (2013). Alat peraga koin bermuatan ini digunakan untuk mengajarkan keempat operasi bilangan bulat. Pada setiap operasi, peneliti membuat aturan penggunaan koin bermuatan. Istilah-istilah operasi pada bilangan bulat juga dibuat serealistik mungkin dengan mengganti dengan kata yang mudah dipahami dalam kegiatan sehari-hari. Sebagai contoh, operasi pengurangan menggunakan istilah pengambilan.

Pada kelas eksperimen, peneliti melakukan cooperative learning dengan media alat peraga koin bermuatan sedangkan pada kelas kontrol pembelajaran dilakukan secara konvensional (ceramah). Langkah berikutnya, peneliti melakukan post-respons sebagai data akhir. Selanjutnya, peneliti melakukan

Copyright $(\odot 2020$

\section{Buana Matematika :}

Jurnal Ilmiah Matematika dan Pendidikan Matematika 
analisis data secara deksriptif dan inferensial. Pada analisis deskriptif, peneliti menentukan rata-rata dan standar devisiasi. Sementara, pada analisis inferensial, peneliti menggunakan uji non-parametrik yaitu uji MannWhitney dikarenakan data diperoleh dari data angket yang berupa data ordinal. Pada langkah akhir, peneliti mengambil kesimpulan yang diperoleh berdasarkan hasil analisis deskriptif dan analisis inferensial.

\section{Hasil dan Pembahasan}

Penelitian melibatkan 64 siswa yang terdiri dari 32 siswa kelas kontrol dan 32 siswa kelas eksperimen. Selama pembelajaran pada kelas kontrol, peneliti mencoba merangsang keaktifan siswa melalui sesi tanya jawab. Sementara itu, pada kelas eksperimen, peneliti membagi siswa menjadi beberapa kelompok kecil untuk mempraktikkan alat peraga dan menyelesaikan lembar kerja. Peneliti selanjutnya membuat sesi presentasi dan diskusi paralel untuk memperdalam konsep materi bilangan bulat.

Pada akhir pembelajaran, peneliti memberikan angket kepercayaan diri siswa dan diperoleh analisis secara deskriptif sebagai berikut.

Tabel 1. Hasil Analisis Deskriptif

\begin{tabular}{lcccc}
\hline \multicolumn{1}{c}{ Kelas } & N & Skor Ideal & $\overline{\boldsymbol{x}}$ & s \\
\hline Eksperimen & 32 & 80 & 55,09 & 4,91 \\
Kontrol & 32 & 80 & 48,34 & 6,52 \\
\hline
\end{tabular}

Berdasarkan pada Tabel 1, terlihat bahwa rata-rata skor kepercayaan diri siswa kelas eksperimen lebih tinggi dibandingkan skor kepercayaan diri siswa kelas kontrol. Hal ini menunjukkan bahwa kepercayaan diri siswa yang memperoleh pembelajaran menggunakan alat peraga koin bermuatan secara deskriptif lebih baik dibandingkan pembelajaran konvensional. Hal ini juga didukung dengan nilai standar deviasi kelas ekperimen yang lebih kecil daripada kelas kontrol. Artinya, persebaran tingkat kepercayaan diri siswa di kelas ekperimen lebih merata dibandingkan kelas kontrol. Hal ini menunjukkan pembelajaran dengan alat peraga koin bermuatan mempengaruhi kepercayaan diri siswa secara lebih kolektif.

Analisis selanjutnya adalah analisis inferensial. Peneliti menggunakan uji Mann-Whitney dengan bantuan SPSS. Berikut analisisnya sebagaimana tersaji di Tabel 2. 
Tabel 2. Hasil Analisis Mann-Whitney

\begin{tabular}{lr}
\hline & Postrespons \\
\hline Mann-Whitney U & 206,500 \\
Wilcoxon W & 734,500 \\
Z & $-4,113$ \\
Asymp. Sig. (2-tailed) & 0,00039 \\
\hline
\end{tabular}

Berdasarkan Tabel 2 diperoleh nilai signifikansi 0,00039. Dikarenakan peneliti menggunakan uji satu arah, maka nilai signifikansi tersebut dibagi 2 sehingga diperoleh 0,0000195. Nilai signifikansi tersebut kurang dari 0,05. Dengan demikian dapat disimpulkan hipotesis peneliti diterima. Dengan kata lain, tingkat kepercayaan diri siswa pada materi operasi bilangan bulat kelas yang menggunakan koin bermuatan lebih tinggi secara signifikan dibandingkan kelas yang menggunakan pembelajaran konvensional. Berdasarkan kedua analisis di atas, alat peraga koin bermuatan mempunyai pengaruh yang signifikan terhadap tingkat kepercayaan diri siswa kelas VII.

Peneliti juga menemukan temuan unik ketika peneliti menggunakan data jumlah skor untuk tiap indikator. Berikut rekap total skor untuk tiap indikator dari tiap-tiap kelas.

Tabel 3. Total Skor tiap Indikator

\begin{tabular}{lcccc}
\hline Indikator & Kontrol & Eksperimen & Selisih & Presentasi \\
KD1 & 408 & 476 & 68 & $17 \%$ \\
KD2 & 247 & 371 & 24 & $10 \%$ \\
KD3 & 453 & 491 & 44 & $10 \%$ \\
KD4 & 439 & 519 & 80 & $18 \%$ \\
Total & 1547 & 1763 & 216 & $14 \%$ \\
\hline
\end{tabular}

Berdasarkan Tabel 3, terlihat bahwa secara umum terjadi perbedaan yang positif pada kelas eksperimen dibandingkan kelas kontrol yakni 216 (14\%). Lebih spesifik lagi, Tabel 3 menunjukkan KD1 dan KD4 mempunyai perbedaan yang signifikan dibandingkan kedua indikator lainnya. Hal ini menunjukkan bahwa penggunaan alat peraga koin bermuatan menjadikan siswa mempunyai kepercayaan pada kemampuan sendiri dan berani mengungkapkan pendapat. 
Kepercayaan siswa terhadap kemampuan dirinya sendiri terlihat pada aktivitas seperti siswa berani mengerjakan soal di depan kelas, tidak merasa cemas ketika diberi tugas, dan yakin dengan hasil pekerjaannya sendiri. Aktivitas tersebut didasari karena siswa sudah merasa paham dengan konsep operasi bilangan bulat melalui pembelajaran realistik berupa koin bermuatan. Pembelajaran yang bersifat realistik akan memudahkan siswa untuk memahami konsep matematika yang abstrak (Laurens, Batlona, Batlona \& Leasa, 2018). Pemahaman yang matang inilah yang dijadikan modal siswa untuk semakin percaya bahwa dirinya siap menyelesaikan permasalahan lain pada operasi bilangan bulat. Hal ini juga selaras dengan penelitian Kosim \& Tirta (2020) yang menunjukkan bahwa pendekatan matematika realistik mempengaruhi kepercayaan diri siswa sebesar 67,1\%.

Selain itu, pembelajaran menggunakan alat peraga juga menunjukkan siswa menjadi lebih berani mengungkapkan pendapatnya. Hal ini terlihat pada proses presentasi dan diskusi saat memperagakan alat peraga koin bermuatan. Proses pembelajaran matematika yang dilakukan secara realistik membuat siswa lebih mudah mengkomunikasikan apa yang dia pikirkan (Ariyanti, 2016). Komunikasi yang dibangun oleh siswa dapat berupa komunikasi verbal maupun tulisan. Siswa yang sudah mampu berkomunikasi baik verbal maupun tulisan merupakan siswa yang tergolong mempunyai kepercayaan diri (Hendriana, Roehati, \& Sumarmo,2017).

Secara umum, penggunaan alat peraga koin bermuatan mampu meningkatkan kepercayaan diri siswa. Hal ini dikarenakan pembelajaran menggunakan koin bermuatan juga mendukung pembelajaran yang eksploratif. Pembelajaran yang eksploratif dapat meningkatkan kepercayaan diri siswa (Maryam \& Aeni, 2016). Pembelajaran ekspolaratif ini menjadikan siswa merasa dilayani dan dipahami oleh gurunya sesuai dengan karakternya, sehingga rasa takut siswa pada pembelajaran matematika dapat diminimalisir. Dengan demikian, pembelajaran dengan alat peraga koin bermuatan mampu membuat siswa berperan lebih aktif.

\section{Simpulan}

Berdasarkan hasil dan pembahasan, penggunaan koin bermuatan pada materi operasi bilangan bulat mempunyai pengaruh yang signifikan terhadap tingkat kepercayaan diri siswa kelas VII SMP Negeri 2 Adimulyo. Penggunaan alat peraga sebagai alat bantu pembelajaran secara realistik terbukti mampu membuat siswa menjadi lebih aktif berpendapat dan percaya pada kemampuananya sendiri. Penelitian ini masih sangat terbatas

Copyright (C) 2020

Buana Matematika :

Jurnal Ilmiah Matematika dan Pendidikan Matematika 
karena alat peraga yang digunakan bersifat spesifik hanya untuk materi operasi bilangan bulat. Oleh karena itu, pada penelitian lainnya, peneliti lain dapat mengembangkan alat peraga lain dengan konsep yang sama yakni pembelajaran realistik yang dapat membantu proses pembelajaran matematika lebih aktif sehingga kepercayaan diri siswa semakin meningkat.

\section{Daftar Pustaka}

Achdiyat, M., \& Lestari, K.D. (2016). Prestasi Belajar Matematika Ditinjau dari Kepercayaan Diri dan Keaktifan Siswa di Kelas. Formatif : Jurnal Ilmiah Pendidikan MIPA, 6(1).

Ariyanti, H.P. (2016). Pengaruh Pembelajaran Matematika Realistik Terhadap Kemampuan Matematis Siswa (Ditinjau dari Kemampuan Representasi dan Komunikasi). Buana Matematika : Jurnal Ilmiah Dan Pendidikan Matematika, 6(2). 37-44.

Hannula, M. S., Maijala, M., \& Pehkonen, E. (2014). Development and Understanding Self-confidence in Mathematics Grade 5-8. Group for Psychology of Mathematics Education, 66(1). 64-74

Hendriana, H., Rohaeti, E.E., \& Sumarmo, U. (2017). Hard Skill dan Soft Skill Matematik Siswa. Bandung : Refika Aditama

Kementerian Pendidikan dan Kebudayaan. (2014). Buku Guru Ilmu Pengetahuan Sosial Kelas VII. Jakarta : Pusat Kurikulum dan Perbukuan, Kemendikbud.

Kosim, A., \& Tirta, I. M. (2020). Analysis of realistic mathematics learning approach on the students' problem solving skill and self-confidence on sequence and series materials. In Journal of Physics Conference Series (Vol. 1465, No. 1 , p. 012031).

Krishna, A. (2006). Neo Psychic Awarenes. Jakarta: PT Gramedia Pustaka Utama

Laurens, T., Batlona, F.A., Batlona, J. R., \& Leasa, M. (2018). How Does Realistic Mathematics Education (RME) Improve Student's Mathematics Cognitive Achievement?. EURASIA Journal of Mathematcs, Science and Technology Educations, 14 (2), 569-578. https://doi.org/10.12973/ejmste/76959

Maryam, S., \& Aeni, A.N. (2016). Pendekatan ekspolaratif untuk meningkatkan kemampuan representasi matematis dan kepercayaan diri siswa. Jurnal Pena Ilmiah, 1 (1), 551-560

Octavianingtyas, E. (2015). Media untuk Mengefektifkan Pembelajaran Operasi Hitung Dasar Matematika Jenjang Pendidikan Dasar. Pancaran Pendidikan, 4(4), 207-218.

Copyright (c) 2020

Buana Matematika :

Jurnal Ilmiah Matematika dan Pendidikan Matematika 
Pratiwi, I.D. \& Laksmiwati, H. (2016). Kepercayaan Diri dan Kemandirian Pada Siswa SMA Negeri" X". Jurnal Psikologi Teori \& Terapan, 7 (1).

Putri, A. (2019). Peningkatan Kemampuan Berpikir Kritis Matematis dan SelfConfidence Siswa yang Memperoleh Pembelajaran dengan Pendekatan Metacognitive Scaffolding. Tesis: Universitas Pendidikan Indonesia.

Siregar, N.R. (2017). Persepsi siswa pada pelajaran matematika : Studi pendahuluan pada siswa yang menyenangi game. Prosiding Temu Ilmiah Nasional X Ikatan Psikologi Perkembangan Indonesia

Suandani, I.(2013). Penggunaan Alat Peraga Koin Bermuatan untuk Meningkatkan Pemahaman Konsep Operasi Penjumlahan dan Pengurangan Bilangan Bulat. Skripsi: Universitas Pendidikan Indonesia.

Winarsih. (2009). Peningkatan Respon Siswa pada Pembelajaran IPS Melalui Pendekatan Keterampilan Proses. Malang: UMP Malang

\section{Riwayat Hidup Penulis}

\section{Siti Makmudah, S.Pd.}

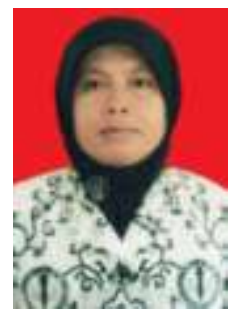

Lahir di Kebumen, 8 Juni 1966. Guru PNS Matematika di SMP Negeri 2 Adimulyo, Kebumen, Jawa Tengah. Studi S1 Pendidikan Matematika Universitas Muhammadiyah Surakarta, lulus tahun 1994.

\section{Yusuf Adhitya, M.Pd.}

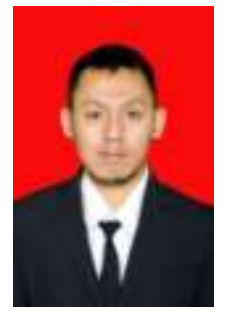

Studi S1 Pendidikan Matematika Universitas Negeri Semarang lulus tahun 2015. Studi S2 Pendidikan Matematika Sekolah Pascasarjana Universitas Pendidikan Indonesia lulus 2019. Topik penelitian yang sering dikaji adalah psikologi matematis dan kemampuan berpikir matematis. 
Jurnal Ilmiah Matematika dan Pendidikan Matematika

Vol. 10 No. 2 (2020)

Copyright $(0) 2020$

Buana Matematika :

Jurnal Ilmiah Matematika dan Pendidikan Matematika

p-ISSN : 2088-3021

e-ISSN : 2598-8077 